\title{
Adolescente em liberdade assistida e a escola
}

\section{Adolescent in assisted freedom and the school}

\author{
Ivani Ruela de Oliveira SILVA ${ }^{1}$ \\ Leila Maria Ferreira SALLES
}

\begin{abstract}
Resumo
Este estudo objetivou investigar as representações e as imagens de profissionais da educação e discentes sobre os adolescentes autores de ato infracional que se encontravam cumprindo medida socioeducativa de liberdade assistida, e sua relação com a escola, bem como as representações e imagens destes últimos sobre a instituição escolar. Para tanto, foram entrevistados alunos matriculados em escolas do município de Americana (SP) em 2007. Foram ouvidos também professores, colegas de classe, funcionários e gestores. Nas entrevistas com os adolescentes, procurou-se perceber os sentidos e os significados que a escola tem para eles e identificar suas representações e imagens sobre ela. Nos demais depoimentos, buscou-se compreender as concepções construídas a respeito daqueles alunos, como as instituições escolares têm atuado no sentido de incluí-los ou excluí-los nos processos formais de escolarização, e como essas representações e imagens se integram nas relações cotidianas e determinam formas de ação.
\end{abstract}

Unitermos: Adolescente. Ato infracional. Escola. Liberdade assistida. Medida socioeducativa.

\begin{abstract}
This study aimed to investigate the portrayals and images of education professionals and students with regard to adolescents who have committed offenses and were serving socio-educational measure of assisted freedom, as well as their relationships with the school and the portrayals and images they have about school as an institution. To this end, we interviewed students from schools in the city of Americana, in the state of São Paulo, in 2007. Teachers, classmates, employees and managers were also given the opportunity to be heard. In interviews with the teenagers, we attempted to find out what the school represents to them and to identify their portrayals and images. In other statements, we sought to understand the conceptions built around these students, how the schools have worked to include or exclude them in the formal processes of schooling and how these portrayals and images fit into daily relationships and determine the form of action.
\end{abstract}

Uniterms: Adolescent. Adolescent in conflict with the law. School. Assisted freedom. Socio-educative measure.

Este estudo objetivou investigar as representações e as imagens de profissionais da educação e discentes sobre os adolescentes autores de ato infracional que se encontravam cumprindo medida socioeducativa de liberdade assistida, e sua relação com a escola, bem como as representações e as imagens desses adolescentes sobre a instituição escolar.
O trabalho surgiu da participação da primeira autora no desenvolvimento do "Projeto Educação e Cidadania", destinado à escolarização dos adolescentes autores de ato infracional privados de liberdade na Unidade de Internação Provisória (UIP) da Fundação Centro de Atendimento Socioeducativo ao Adolescente (Fundação CASA), antiga Fundação Estadual do Bem-

$\boldsymbol{\nabla} \mathbf{v} \boldsymbol{\nabla}$

1 Universidade Estadual Paulista, Programa de Pós-Graduação em Educação. Av. 24-A, 1515, Bela Vista, 13506-900, Rio Claro, Brasil. 
-Estar do Menor (FEBEM-SP), instalada no Núcleo de Atendimento Integrado de Americana (NAIA). O estudo realizado com esses adolescentes levou à busca pelo entendimento do significado que a escola tem para eles e do modo como as instituições escolares têm atuado para incluir os adolescentes em liberdade assistida nos processos formais de escolarização ou excluí-los desses processos.

A discussão sobre inclusão escolar implica obrigatoriamente pensar e discutir também a exclusão escolar, uma vez que, segundo Gentili (1995), estar excluído na educação pode tanto significar estar fora da escola como ter acesso a uma escola de baixa qualidade. Assim, se, por um lado, uma política educacional é considerada excludente porque nega ou limita a possibilidade de permanência do aluno na instituição escolar, por outro, só será inclusiva a política educacional que possibilitar aos alunos tanto seu acesso quanto sua permanência nela.

Ferraro (1999), ao analisar a exclusão na escola, diferenciou-a em exclusão da escola e exclusão na escola. Para ele, a exclusão da escola compreende tanto o não acesso como a evasão escolar, enquanto a exclusão na escola representa a exclusão produzida dentro do processo escolar por meio da reprovação e da repetência.

Para Dubet (2003), analisar o papel da escola no processo de exclusão escolar implica reconhecer os mecanismos pelos quais ela, por sua própria ação, acrescenta fatores de desigualdades e exclusão que ultrapassam a simples reprodução das desigualdades sociais.

A partir dessas e de outras questões, procurou-se analisar como os adolescentes em conflito com a lei justificam o ato infracional, elaboram seus projetos de vida e constroem representações e imagens sobre a escola e os estudos, bem como compreender as concepções que educadores, funcionários e colegas de classe constroem sobre o adolescente autor de ato infracional e sua relação com a escola. Por meio dessas análises, procurou-se perceber como essas representações e imagens integram-se nas relações cotidianas da escola e determinam formas de ação, seja para facilitar a inclusão do adolescente em liberdade assistida no espaço escolar, seja para contribuir com sua exclusão.

\section{Sobre o adolescente autor de ato infracional}

De acordo com Londoño (1992), a palavra "menor" começou a aparecer no vocabulário jurídico brasileiro a partir do final do Século XIX e início do XX; anteriormente, seu uso não era comum e seu significado era restrito. A partir do referido período, o vocábulo "menor" foi aos poucos sendo ressignificado, deixando de ser associado à idade quando se tratava de definir a responsabilidade de uma pessoa perante a lei e passando a designar crianças e adolescentes pobres e abandonados e ainda aqueles que praticassem delitos. O"menor" não era o filho de família sujeito à autoridade paterna, nem o órfão tutelado, mas, sim, a criança ou o adolescente desprotegido e desamparado tanto material como moralmente pelos seus pais, tutores, pela sociedade e pelo Estado.

No fim do Século XIX, segundo Londoño (1992), os juristas brasileiros descobrem o "menor" nas crianças abandonadas e nos adolescentes pobres que não estavam sob a responsabilidade dos seus pais e tutores e que, por incorrerem em delitos, frequentavam o xadrez e a cadeia; nesse caso, passavam a ser chamados de "menores criminosos".

Essa concepção de "menor"foi sendo veiculada pelos meios de comunicação, por políticos e acadêmicos, e, aos poucos, o termo estava claramente identificado com a parcela da população desamparada socialmente (Londoño, 1992). Nessa época, a infância e a adolescência abandonadas e desamparadas eram tratadas como caso de polícia, e as crianças e os adolescentes nessa situação, vigiados e reprimidos, pois eram vistos como delinquentes em potencial.

Menoré, portanto, a forma jurídico-social do controle
estatal sobre as crianças e jovens do proletariado
que estão condenados ao estigma pela sua condição
de possível infrator, identificado como delinquente
pelo saber das instituições austeras (Passetti, 1992,
p.172, grifo do autor).

Embora essa atitude de tratar as crianças e os adolescentes nessa situação como caso de polícia tenha perdurado por vários anos, tal postura é criticada e os juristas começam a postular a necessidade de uma mudança na atuação do Estado e a reivindicar a criação de uma lei de proteção ao "menor". Com o Governo Vargas, a infância e a adolescência pobre e desamparada 
deixam de ser concebidas e tratadas como um problema policial e passam a ser reconhecidas como uma questão social (com base no Código Criminal de 1830, no Código Penal Brasileiro de 1890, no Código Civil de 1916, na Lei n 4.242 de 1921 e no Código de Menores de 1927). A partir dos anos 1940, a assistência social passa a constituir a base da legislação e dos programas destinados aos ainda chamados "menores" (com fulcro principalmente nos seguintes diplomas legais: Decreto-Lei n० 2.848, de 1940; Decreto n 6.026 de 1943; Lei no 3.133 de 1957; Lei no 4.513 de 1964; Lei no 5.439 de 1968 e Lei no 6.697 de 1979).

Somente na década de 1990, com a aprovação da Lei no 8.069/90 - Estatuto da Criança e do Adolescente (ECA), são rompidos os paradigmas anteriores, que eram calcados no assistencialismo e que tratavam a criança e o adolescente pobres como caso de polícia. O ECA fundamenta-se na Doutrina da Proteção Integral, que por sua vez concebe as crianças e os adolescentes como sujeitos de direitos (Centro de Estudos e Pesquisas em Educação, Cultura e Ação Comunitária, 2003; Rizzini, 1995), e representa um verdadeiro divisor de águas. Com ele muda-se o paradigma e passa-se a compreender que não são as crianças e os adolescentes que estão em "situação irregular", e sim as condições a que estão submetidos (Cabral \& Sousa, 2004; Volpi, 1999).

A perspectiva da doutrina da proteção integral implica reconhecer que, para que se desenvolvam plenamente, crianças e adolescentes necessitam de proteção, que enseja atendimento e cuidados especiais.

Art. 3․ A criança e o adolescente gozam de todos os direitos fundamentais inerentes à pessoa humana, sem prejuízo da proteção integral de que trata esta Lei, assegurando-se-lhes, por lei ou por outros meios, todas as oportunidades e facilidades, a fim de Ihes facultar o desenvolvimento físico, mental, moral, espiritual e social, em condições de liberdade e de dignidade (Brasil, 1990).

Assim, o ECA, como aponta Rizzini (1995, p.167) "rompe com paradigmas secularizados pela tradição, deslocando da esfera estritamente jurídica questões que se atrelam ao campo da luta política e social por direitos, o país revisita posturas e práticas antes tidas como inabaláveis".

Com o novo estatuto, abandona-se definitivamente o termo "menor" - tanto para designar as crianças e os adolescentes pobres e desamparados como aqueles que cometeram delitos -, por ser carregado de preconceitos e interdições. Nesse sentido, Volpi (2001, p.21) afirma preferir as "expressões adolescente autor de ato infracional e adolescente em conflito com a lei ao invés de adolescente infrator, por apresentarem uma circunstância de vida e não uma categoria valorativa".

Entretanto, como diz Passetti (1992, p.172), substituir o termo "menor" para criança e adolescente pode significar apenas uma modernização terminológica desprovida de sentido prático.

Entre as medidas socioeducativas previstas no ECA, encontra-se a liberdade assistida à qual o adolescente autor de ato infracional está sujeito. Essa medida é aplicada quando a autoridade competente conclui pela necessidade do acompanhamento da vida social do adolescente, que compreende a escola, o trabalho e a família. A intervenção educativa implica o acompanhamento personalizado do adolescente visando a sua proteção, inserção comunitária, manutenção de vínculos familiares, frequência à escola e inserção no mercado de trabalho e/ou cursos profissionalizantes e formativos (Volpi, 1999, p.24).

Mesmo que as medidas socioeducativas, como a de liberdade assistida, comportem aspectos coercitivos - uma vez que são punitivas aos autores de ato infracional - (Volpi, 1999), elas são mecanismos que asseguram, dentre outros direitos, a frequência à escola. O direito à educação deve ser garantido até mesmo nas situações em que o adolescente se encontre privado de sua liberdade. Para Volpi (1999), os projetos educativos a serem desenvolvidos nas unidades de internação devem possibilitar a construção de um conjunto de conhecimentos e saberes que ajude essas pessoas a se localizarem no mundo e que contribua para seu regresso e permanência na rede regular de ensino. O objetivo maior desses projetos pedagógicos deve ser a formação para a cidadania e, para tanto, deve propiciar espaço para que o adolescente reflita sobre os motivos que o levaram à prática do ato infracional.

Não obstante todos esses avanços, tanto os documentos quanto a literatura referentes ao atendimento à criança e ao adolescente no Brasil mostram que, principalmente em relação à parcela empobrecida desse segmento da população, o "atendimento" oferecido 
desde o Brasil Colônia até os dias de hoje é ainda repressivo e discriminatório. Consoante Marcílio (1998) e Del Priore (1999), a história tem mostrado que existe um verdadeiro abismo entre o proclamado na legislação e nas políticas públicas e a realidade dessa parcela da população.

Entretanto, mesmo que o ECA não tenha ainda sido efetivamente implantado, esse estatuto tem sido enfaticamente criticado por parcelas da sociedade por "dar" muitos direitos a crianças, facilitar a impunidade e exigir poucos deveres (Silva, 1998).

Nas escolas investigadas, críticas como essas são comuns. Muitas vezes, os educadores dizem que estão de mãos atadas diante das crianças, que não podem mais ser reprimidas ou chamadas ao dever. Eles queixam-se por serem chamados ao conselho tutelar para se explicar quando agem de forma que os adolescentes e seus pais não aceitam.

Surgem, portanto, algumas indagações: como têm sido a acolhida e a integração do adolescente autor de ato infracional nas escolas, considerando-se que o ECA garante o direito daqueles que estão em liberdade assistida? Como os educadores têm agido para facilitar a inclusão desses alunos? Foi a partir desses questionamentos que esta pesquisa foi desenvolvida.

\section{Método}

Este estudo de natureza qualitativa caracterizou-se como uma pesquisa descritiva porque visava ao estudo e à descrição das características, propriedades e relações existentes na comunidade, grupo ou realidade pesquisada, objeto deste estudo (Cervo, Bervian \& Silva, 2007).

Os dados foram coletados por meio de observação, análise de documentos e entrevistas. A investigação foi desenvolvida em todas as escolas de ensino fundamental e/ou médio dos Municípios de Americana e Santa Bárbara d'Oeste, nas quais estavam matriculados alunos egressos do NAIA no primeiro semestre letivo do ano de 2007. Para tanto, foi feito um levantamento, junto à Diretoria de Ensino da Região de Americana, de todos os adolescentes internados na UIP desde 2005.

Esse mapeamento mostrou que, durante os anos de 2005 a 2007, 120 adolescentes estiveram em regime de internação provisória nessa unidade. Destes, somente
32 adolescentes egressos do NAIA e que estavam cumprindo medida socioeducativa em meio aberto, ou seja, em liberdade assistida, matricularam-se em escolas públicas daqueles municípios no ano letivo de 2007. Desse total, 4 estavam matriculados no ensino fundamental, 11 no ensino médio, 14 no ensino fundamental - modalidade EJA - e 3 no ensino médio - modalidade EJA. Entretanto, quando da visita às escolas onde esses adolescentes estavam matriculados, verificou-se que apenas 5 deles frequentavam a escola regularmente, 4 apresentavam frequência irregular, 21 estavam evadidos e 2 internados para tratamento de saúde.

A partir dessas informações, o campo de trabalho restringiu-se a nove escolas, nas quais estudavam os alunos com frequências regulares e irregulares. No entanto, embora se tenha comparecido assiduamente às escolas em que os estudantes com frequência irregular estudavam, não foi possível contatá-los, o que pode indicar que, mesmo constando oficialmente como matriculados, esses alunos estavam evadidos. Assim, o número de escolas em que foi desenvolvido este trabalho ficou restrito. $\mathrm{O}$ estudo foi então realizado nas três instituições escolares nas quais estavam estudando os cinco alunos com frequência regular.

Os cinco adolescentes são do sexo masculino, com idade entre 15 e 17 anos. Quatro deles são filhos de pais separados e moravam com suas mães, que trabalhavam em funções não especializadas. Apenas um adolescente estava trabalhando quando entrou em conflito com a lei. Um deles havia se envolvido com tráfico de drogas, outro com tráfico de drogas e extorsão, outros dois tinham cometido roubos e um foi acusado de ter cometido ato infracional análogo a atentado violento ao pudor.

Em uma das escolas intitulada Escola 1, foram entrevistados 3 adolescentes autores de ato infracional, a vice-diretora, uma professora de língua portuguesa, uma agente de organização escolar e 3 colegas de classe (sendo um de cada sala de aula em que esses alunos em liberdade assistida estudavam). Na instituição denominada Escola 2, os entrevistados foram: um adolescente em conflito com a lei, um colega de classe, a professora-coordenadora, uma professora de língua portuguesa e uma agente de organização escolar. Na terceira instituição, denominada Escola 3, foram entrevistados um adolescente em liberdade assistida, um 
colega de classe, a diretora, uma professora de língua portuguesa e uma agente de organização escolar.

Os professores de língua portuguesa, que lecionavam nas salas de aula em que estudavam os alunos participantes desta pesquisa, foram entrevistados pelo fato de ser essa uma das disciplinas com maior número de aulas semanais. Os colegas de classe que participaram das entrevistas foram sorteados. Todas as entrevistas foram semiestruturadas (Bogdan \& Biklen, 1994). O roteiro foi construído a partir de temas e subtemas que procuraram contemplar os objetivos da investigação, bem como para servir como guia nos questionamentos feitos com cada entrevistado.

Em cada escola, foram também realizadas observações. Procurou-se analisar a interação estabelecida entre os alunos em cumprimento de medida socioeducativa e os professores, funcionários, gestores e outros alunos. A averiguação foi feita nas salas de aula e demais espaços escolares, como o pátio, nos momentos de intervalo das aulas. Essas observações foram utilizadas como dados complementares aos obtidos por meio das entrevistas. Com o objetivo de analisar a trajetória escolar dos alunos desta pesquisa, foram analisados, junto à escola, seus históricos e registros escolares, nos quais se verificaram dados relativos à frequência, à evasão, a ocorrências disciplinares e ao desempenho escolar.

Para análise dos depoimentos e sua categorização, baseou-se em Lüdke e André (1986) e em Bardin (2007) e buscou-se comparar o depoimento dos alunos em cumprimento de medida socioeducativa com o dos demais entrevistados, analisar a trajetória escolar daqueles estudantes e as observações. A partir dessas análises, procurou-se perceber os sentidos e os significados que a escola tem para esses alunos e como as instituições escolares têm atuado para incluir os adolescentes em liberdade assistida aos processos formais de escolarização ou para excluí-los desses processos.

\section{$O$ adolescente infrator em liberdade assistida e a escola}

Os adolescentes entrevistados, ao falarem do ato infracional que cometeram, justificam sua ação pelo dinheiro que podem obter por meio do tráfico de drogas; pela facilidade de entrar em situações desse tipo, já que residem em locais onde existe o tráfico; pelo uso de drogas; pela influência de amigos; por relações familiares problemáticas e pela proibição do trabalho adolescente. Nesse último caso, a proibição ao trabalho os privaria de meios legais de sustento financeiro.

Quando se referem à escola, os adolescentes dizem que as boas lembranças estão ligadas às amizades que estabeleceram e ao coleguismo, e as más recordações às brigas com os colegas. O relacionamento com os professores e demais funcionários das instituições escolares é marcado por atitudes ambivalentes. Às vezes, ele é valorizado, às vezes, é criticado como desrespeitoso, mesmo que eles próprios, eventualmente, culpem-se pelas dificuldades na interação com os profissionais da escola, já que, como dizem, fazem bagunça. Porém, essa culpa é relativizada quando dizem que, por não os xingar, respeitam-nos.

A referência ao respeito e/ou desrespeito nas relações aparece sempre presente em suas falas, até mesmo quando se aponta o que está faltando ou o que precisaria ser modificado no trabalho realizado pela escola: "ensinar o respeito para os outros porque tem muita gente que não sabe o que é respeito não".

A trajetória escolar desses alunos, como mostram os depoimentos seguintes, é pontuada por conflitos. Eles são transferidos e/ou expulsos das escolas que frequentam:

Tive que fazer minha transferência. A escola me obrigoua
me retirar. Acho que davam graças a Deus, nãoé? Estava
no 10 ano do ensino médio, fez uma reunião, minha mãe
foi lá, eles pediram pra mim ser retirado e arrumarvaga
em outra escola porque lá não podia mais estudar.
Falaram que se eu não fosse, não ia arrumar vaga mais
em nenhuma escola. Aí eles obrigaram meu paieminha
mãe a arrumar vaga pra mim.

Eu estudei até a quinta série aqui. Aíeu fui expulso daqui, aíme mandaram pro W (inicial do nome da escola para a qual ele foi transferido) e eu fiquei até a sétima série lá. Aí depois da sétima eu vim pra cá.

Falaram o que eu tinha queestudar, que eles não iam me repetir por causa de tudo o que já tinha acontecido comigo, que tinha ido para o NAIA e já tinha perdido matéria. Me ajudaram, eu estou no $1{ }^{\circ}$ ano agora, graças a Deus, não me repetiram de ano, só que quando eu fui conversar, só que quando a minha mãefoi fazer a minha rematrícula pra eu ir pro $10^{\circ}$ ano eles não aceitaram. Eles falaram que eu ia ter que vim pra Escola 3. Aí apro- 
veitaram, aproveitaram que eu mudei de lugar e já me encaminharam pracá.

Essas transferências são apontadas, inclusive, como causa para a interrupção dos estudos: "Não procurei outra escola porque eu estava com intenção de fazer o supletivo no ano seguinte".

Mesmo com essa trajetória marcada por transferências compulsórias, que acabam apontando para uma discriminação, todos os adolescentes, quando indagados sobre se já foram discriminados na escola onde estudavam na época da pesquisa, responderam negativamente. Ao falar de discriminações, eles sempre se referem às escolas anteriores:

Eu sempregostei da outra escola, então a málembrança foi que tudo o que aconteceu comigo, que eu fiz um ato infracional mesmo, foi a discriminação, porque eles sempre me tratavam bem e depois que eu tive minha passagem pelo NAIA daíeles não aceitaram mais. Eu senti que eles não me queriam mais na escola, por causa de outras vezes que entrava outros alunos que tinham problema, eles tiravam, eles arrumavam um jeitinho do aluno fazer uma baguncinha pra eles expulsá-los da escola.

Ressalta-se, nesse depoimento, que era comum a direção da escola utilizar-se de estratagemas para livrar-se dos "alunos-problemas", que, como o autor do depoimento acima, tornavam-se indesejáveis.

Todas essas falas indicam que as relações pessoais com colegas e educadores, mesmo que marcadas por conflitos e ambiguidades - ser amigo/brigar, ser respeitado/ser desrespeitado, ser discriminado/não ser discriminado -, são, para eles, aspectos centrais na escola. Embora um adolescente tenha se queixado de que as instituições escolares dão muita liberdade aos alunos, que, assim, aproveitam para não estudar ou não permanecer na sala de aula, nenhum deles, ao falar da escola, destacou a importância dos conteúdos escolares.

Em geral, eles não participam e nem são chamados a participar da vida escolar no que diz respeito às instâncias e aos colegiados existentes nas escolas, pois apenas um dos entrevistados disse ter sido indicado para ser representante de sua classe. Eles não compõem nenhuma das instituições ou colegiados escolares: grêmio estudantil; associação de pais e mestres; conselho de escola e conselho de classe e série. Também não são indicados para serem representantes de classe. Prova- velmente, para esses alunos considerados problemas e que muitas vezes são, conforme apontam, discriminados nas escolas que frequentam, a participação nos colegiados e nas instituições escolares está vedada, embora a formação para a cidadania, como assinalou Volpi (1999), seja central na formação desses adolescentes que entraram em conflito com a lei.

Porém, mesmo com todas as dificuldades apontadas na sua relação com a escola, esses alunos consideram-na importante para suas vidas e seus projetos futuros:

Porque sem a escola a gente acaba tendo emprego que ganha pouco. Hoje precisa ganhar bastante para pagar aluguel, força, para ser alguém na vida. Atépara ser lixeiro as pessoas falam que tem que ter o primeiro ano (do ensino médio).

Eu não vou parar de estudar não. Para eu sair formado da escola, fazer uma faculdade.

Porque que sem a escola a gente não ia saber viver. Pra falar bem a verdade se não fosse a escola, o que seria da gente? Não seria nada. A pessoa aprende educação em casa e aprende educação na escola. Nem é por causa tanto da matéria, mas é por causa do professor mesmo que ele ensina, explica certinho as coisas como que devem ser feitas, não é do jeito que você pensa e isso ajuda um pouco a pessoa.

No entanto, desperta atenção o fato de a escola ser percebida somente na relação com sua vida futura, especificamente, quanto à possibilidade de se conseguir um bom emprego e de permitir o acesso ao ensino superior. Essas falas nos levam a inferir que a escola, para eles, não é percebida no tempo presente. Ela não é entendida como uma instituição que participa da sua formação em nenhuma das dimensões pessoal, cultural, política ou social. Isso indica que esses alunos têm uma visão utilitarista da escola, aproximando-se assim do significado que ela tem para os estudantes das camadas populares (Charlot, 1996). Adorno (1991) corrobora essa tese quando aduz que a instituição é sentida de forma antagônica: familiar e distante ao mesmo tempo.

\section{Outros atores do cenário escolar}

Os professores, os gestores e os agentes de organização escolar - aqui designados como profissionais da escola ou educadores -, ao falarem sobre o papel da 
instituição escolar na vida de um aluno que cometeu ato infracional, dizem que cabem a ela: oferecer ajuda psicológica; complementar a família na sua função de cuidar da crianças; buscar ajuda de promotores de justiça e de pedagogos; enfrentar os problemas relacionados ao uso de drogas; ensinar; informar; orientar; privilegiar currículos voltados para um trabalho que favoreça as inter-relações pessoais; não se fixar apenas na promoção de seus alunos no final do ano letivo, mas prepará-los para o exercício da cidadania; punir; promover a inclusão escolar; promover a igualdade, trabalhando de forma diferenciada com os alunos que necessitam; promover o trabalho coletivo; estabelecer relações dialógicas entre alunos, professores e demais funcionários e propiciar o encontro com os amigos. Assim, a interrupção dos estudos é vista como problemática, pois impede a escola de cumprir suas funções, e é apontada como um dos motivos que levam um adolescente a entrar em conflito com a lei.

Entretanto, as falas dos entrevistados a respeito da interrupção dos estudos são contraditórias, uma vez que se têm, de um lado, as percepções anteriores quando eles se referem de forma genérica à importância da escola na vida do adolescente que cometeu um ato infracional e que, muitas vezes, extrapolam as funções que the são inerentes por não serem de sua responsabilidade e competência, e, de outro, as referências a esses adolescentes concretamente:

Agora, deixar esse aluno fora da escola, ai que bom, que alívio, isso eu acho que é muito errado, porque, com certeza a genteestá contribuindo para aluno na rua, para cometer ato infracional, é pra ir pra um lado que realmente não convém (professora-coordenadora, E2).

Quando ele é expulso da escola éporque elejá aprontou muito dentro da escola. Ele teve todas as chances pra fazer enão fez. Então, éem último caso só que acontece isso (professora, E1).

Assim, no concreto das relações com o adolescente em liberdade assistida na escola, a expulsão dos alunos é, às vezes, justificada pelos profissionais da escola, e a interrupção dos estudos é vista como prejudicial por permitir um tempo ocioso e não pela importância da escola na formação do adolescente.

Os colegas, em sua maioria, dizem que ser expulso da escola pode contribuir para que um adolescente cometa ato infracional e, como os educadores, parecem entender que o maior problema está no tempo ocioso quando não se frequenta a escola:

Éum tempo que ele está meio preso aqui. Se você tirá-lo daqui ele vai ficar com esse tempo vago, então pode ser que como ele não tem nada pra se ocupar ele acaba fazendo coisas erradas. Eu acho que ajuda mais ele fazer coisas erradas. Expulsar o aluno, jamais pode fazer isso como aluno porque está jogando ainda mais ele ainda pro mundo perdido (colega, MM1).

O tempo de permanência nas ruas ocasionado pelo ócio é apontado como fator relevante para a transgressão das normas legais, e, desse modo, as falas dos colegas de classe se parecem com a dos educadores. Ainda, assemelhando-se aos profissionais escolares, os colegas, ao falarem sobre o papel da escola junto ao adolescente autor de ato infracional, destacam: lutar para que o aluno permaneça nela e não o marginalizar através da expulsão; trabalhar para a formação e o desenvolvimento humanos; desenvolver um trabalho diferenciado, com ênfase na qualificação para o trabalho; constituir-se numa nova oportunidade de aprendizado e de promoção de mudanças que contribuam para um recomeço. Ou seja, às vezes, as funções da escola se ampliam e abarcam várias competências e outras vezes reduzem-se à ocupação do tempo livre dos adolescentes.

O dever da escola é de ensinamento, tinha que ser cumprido, não é? E com esse aluno eu acho que tinha que ser um preparo mais especial, assim, com ele. Porque a escola pode ajudá-lo a ser um cara capacitado. Pode serum professor, alguma coisa assim, no futuro. Então, é, todo mundo merece isso, não é? Mais eu acho que pra com eles tinha que ter um caso mais especial porque ele queria mudar mesmo (colega, E1).

Tem algumas escolas que, como nem tem aula, essas coisas, elevaipraticamente se sentir em casa, pracometer erros, não é? Tem algumas escolas que eu considero porque eu vique o aprendizado pode ir pra frente, igual a Escola 1. Aídepende também da escola, também, porque a escola, acredita em si falar: eu vou, quero formar gente do bem, quero formargente capacitada para o mercado de trabalho, essa aívai ser considerada a melhorescola. É, muito importante, sem escola, todo mundo, acho que, nem meus próprios pais iam conseguir me ensinar a educação que eu tenho hoje, não é? É importante porque tipo, ele pode mudar, conseguir construir seu futuro de novo, aprendendo, pode ser que nessa vida dele que ele começa de novo uma nova chance (colega, E1). 
Dos colegas de classe entrevistados, apenas dois declaram ter conhecimento de que na escola onde estudavam existiam alunos em conflito com a lei:

Tem. Na minha classe mesmo tem. Acho queéesse só. Ele fala. Ele vaiter julgamento agora e ele está com medo de ser preso porque ele era menor, mas agora pode ser que ele pode ser preso. Ainda ele émenorné? (colega, E1).

Sei sim. Ele passou pelo NAIA. Ele mesmo já tocou no assunto que ele foi preso. Na hora eu fiquei espantado porque por mim, pelo que eu conversava, pra mim, ele era meio da pá virada, ele fazia muita bagunça, mas, nunca foi daqueles de cometer atos desse jeito. Edaí, na hora eu fiquei meio espantado. Poxa, o cara! Eu não sabia. Daína hora eu me toquei. O caraédessejeito, não é? (colega, E2).

De modo diferente, todos os profissionais afirmaram ter conhecimento de que na escola havia alunos que cometeram ato infracional:

Se eu conheço algum? Eu ouço comentário. Às vezes o aluno chega e diz: eu não estava vindo porque eu estava internado. Alguns falam, chegam e falam. Esses dias, chegou um e eu falei, ô, sumiu da escola! Ele falou: eu estava internado. Aíeu falei. Vocêestava doente? Elefalou: não, eu estava no NAIA, estudando lá. Eu nem imaginava ser ele. Ele é um bom menino (agente de organização escolar, R1).

Sim, claro, temos dois, temos vários acho. Eu dou aula para dois. O J eu não conhecia não, eu conheciele só esse ano, mas eu fiquei, sabe assim, eu fiquei assim, até assustada porque esse aluno na sala de aula é uma gracinha. Um aluno aplicado. Outro dia atéfalaram, que gracinha! Ele pede porfavor, obrigado. Atéeu fiquei assim surpresa com o J. O coordenador que nos avisou que o J estava faltando porque ele estava no NAIA e que ele iria faltar por algum tempo (professora, E1).

Causa estranheza, nessas falas, a surpresa por não "imaginarem" que "um bom menino" ou um "aluno aplicado e cortês" possa ser autor de ato infracional. Parece haver, por parte desses profissionais, uma expectativa de que um aluno em conflito com a lei comporte-se mal na escola e não se dedique aos estudos.

Ao falarem dos adolescentes em liberdade assistida na escola, os educadores dizem que eles não se distinguem dos outros, que podem mesmo ser até mais indisciplinados e desinteressados:

o J não dá problema nenhum. Agora, têm outros que 360

não querem, porque eles também precisam querer ser ajudados. Porque, se eles querem ser recuperados eles têm que se ajudar também. Mas se eles não querem, é muito difícil. Eles atéestão na aula, mas eles não fazem nadae eles atrapalham a aula. Não é uma via de regra assim queémais difícil. Com alguns é, outros, não (professora, E1).

Não, eu acho queénormal. Eu acho mais difícil trabalhar com criança do que com adolescente (agente de organização escolar, R1).

Os depoimentos indicam, assim, que os adolescentes em conflito com a lei não são os únicos que apresentam problemas disciplinares. Outros alunos se envolvem em transgressões às normas escolares. Essas falas parecem, então, demonstrar que os eventuais problemas encontrados para se trabalhar com os alunos em liberdade assistida são os mesmos que se verificam com demais estudantes da escola, ou seja, eles não se comportam de forma diferente dos demais alunos.

Entretanto, tratar esses estudantes como iguais aos demais ou tratá-los de forma diferente é uma dúvida que parece estar sempre presente entre os profissionais da escola:

Eles são tratados como alunos normais, porque aqui dentro a gentenão comenta: fulano veio do NAIA, e o que seja que ele tenha cometido, entendeu? Mesmo porque, às vezes nem os professores sabem porque aquele aluno está aquidentro, o que aconteceu com ele. Aqui, a gente não trata aluno dessa maneira. Ele aqui é um aluno normal. Ele não é discriminado (vice-diretora, E1).

Assim, écomo eu falei, às vezes, de repente, quando vem de alguma outra escola com algum problema eu prefiro não falar. Quer dizer, porque ele, se eu chegar e falar... . Têm professores, funcionários também, porque ele jávem com aquela marca. Porque que há discriminação nós sabemos que há (diretora, E3).

Essas falas mostram, portanto, uma contradição entre revelar aos demais quem é o aluno que cometeu um ato infracional e não contar aos demais, para evitar discriminações.

Aqui na escola? Ah! Eu sinto sim que tem por parte de alguns professores que falam: ah, também aquele menino lá, o que se vai esperar dele? Nada! Tem uns meninos aí que nós vamos reunir o Conselho amanhã, (essa reunião foi convocada para decidir sobre transferência compulsória) não sei, acho que não passaram pelo NAIA ainda, mas eles estão, assim, 
preocupadíssimos, se eles vão continuar aqui na escola, se não vão, porque eles adoram a escola (professora, E1, grifo nosso).

Destaca-se a expectativa dessa professora quanto ao futuro dos alunos considerados "problemáticos" pela escola. Para ela, parece que o caminho natural é que eles acabem internados no NAIA. Dessa forma, a escola parece não ter o que fazer a não ser esperar a concretização dessa trajetória ou ainda contribuir para isso, pois, a aplicação do dispositivo disciplinar chamado "transferência compulsória" - apesar de previsto no regimento escolar - configura-se, concretamente, um eufemismo usado para camuflar o processo de expulsão do aluno, constituindo-se, portanto, um instrumento de exclusão escolar.

A discriminação diante do adolescente autor de ato infracional, contudo, não é uma questão apenas dos profissionais da escola. Entre os próprios alunos há relatos de situações desse tipo: "Às vezes as pessoas ficam um pouquinho diferentes com ele porque sabem como ele é. O que ele pode fazer entendeu? Tipo assim, já houve alguma discussãozinha, mas de brincadeira, a pessoa vai e envolve as coisas que ele já fez e manda ele ficar quieto" (colega, E2).

Os relatos tanto dos educadores quanto dos colegas indicam que, nas três escolas estudadas, ocorrem atitudes discriminatórias em relação a esses adolescentes.

Tudo isso sugere que os profissionais da escola e os colegas de classe dos adolescentes em liberdade assistida se enveredam em contradições: tratar igual, tratar diferente, contar que na escola existem alunos nessa situação, esconder, expulsar ou transferir compulsoriamente, aceitá-los e acolhê-los como alunos.

\section{Considerações Finais}

As escolas, em geral, como assinalam os depoimentos coletados e que foram corroborados pelas observações realizadas em diferentes momentos, muitas vezes discriminam esses estudantes, de modo que a igualdade apregoada não traduz a realidade. $O$ estudo apontou a dificuldade que a instituição escolar tem para trabalhar com alunos considerados "problemas", sejam eles autores de ato infracional ou apenas estudantes considerados indisciplinados ou ainda protagonistas de violência, embora a literatura há vários anos indique que a escola não pode trabalhar apenas com alunos idealizados, mas com estudantes reais.

Esses estudantes, portanto, percebem a escola como importante e, ao mesmo tempo, convivem com a possibilidade de serem expulsos, de serem transferidos, ou de se evadirem - mesmo que a frequência à escola seja obrigatória por decisão judicial. Assim, embora formalmente se afirme a necessidade de incluí-los, sua trajetória escolar é marcada por processos que contribuem para sua exclusão do sistema educativo. Desse modo, os alunos em liberdade assistida podem estar vivendo um processo de exclusão escolar, às vezes mais escancarado e às vezes mais sutil. Esse processo tem consequências em suas vidas, por isso, compreender o problema da exclusão pressupõe não apenas identificar quem é excluído, mas conhecer também os processos e as implicações dessa exclusão sobre quem a sofre.

A oferta escolar não é homogênea e, por isso, não produz sempre nos alunos o mesmo desempenho nem alcança a mesma eficácia. Diversos mecanismos próprios do funcionamento da escola acabam beneficiando os alunos mais favorecidos socialmente e que já dispõem de maiores recursos para o sucesso do que os outros. Se isso é verdade para o estudante de classes desfavorecidas, é mais verdadeiro ainda para aqueles que, além de viverem nessas condições socioeconômicas, cometeram ato infracional e cumprem medida socioeducativa enquanto estão matriculados nas escolas.

Neste estudo, ao se procurar compreender as concepções que os educadores, funcionários e alunos constroem sobre o adolescente autor de ato infracional e sua relação com a instituição escolar, pôde-se perceber que essas representações e imagens integram-se nas relações cotidianas da escola e determinam formas de ação. Constatou-se também que, apesar de os adolescentes em liberdade assistida reconhecerem o valor dos estudos e afirmarem a importância da escola para suas vidas, eles não permanecem nela.

\section{Referências}

Adorno, S. (1991). A socialização incompleta: os jovens delinqüentes expulsos da escola. Cadernos de Pesquisa, 79, 76-80.

Bardin, L. (2007). Análise de conteúdo. Lisboa: Edições 70. 
Bogdan, R. C., \& Biklen, S. K. (1994). Investigação qualitativa em educação. Portugal: Porto Editora.

Brasil. (1990). Lei no. 8069, de 13 de julho de 1990. Estatuto da criança e do adolescente. Brasília: Senado.

Cabral, S. H., \& Sousa. S. M. G. (2004). O histórico processo de exclusão/inclusão dos adolescentes autores de ato infracional no Brasil. Psicologia em Revista, 10 (15), 71-90.

Centro de Estudos e Pesquisas em Educação, Cultura e Ação Comunitária (2003). Coleção educação e cidadania: 17 módulos. São Paulo: CENPEC.

Cervo, A. L., Bervian, P. A; Silva, R. (2007). Metodologia científica (6a ed.). São Paulo: Pearson Prentice Hall.

Charlot, B. (1996). Relação com o saber e com a escola entre estudantes da periferia. Cadernos de Pesquisa, (97), 47-63.

Del Priore, M. (Org.) (1999). História das crianças no Brasil. São Paulo: Contexto.

Dubet, F. (2003). A escola e a exclusão. Cadernos de Pesquisa, (19), 29-45.

Ferraro, A. R. (1999). Diagnóstico da escolarização no Brasil. Recuperado outubro 24, 2008, disponível em: <http:// www.anped.org.br/rbe/rbedigitals.

Gentili, P. (Org.) (1995). Pedagogia da exclusão: crítica ao neoliberalismo em educação. Petrópolis: Vozes.

Londoño, F. T. (1992). A origem do conceito menor. In M. Del Priore (Org.), História da criança no Brasil. São Paulo: Contexto.
Lüdke, M., \& André, M. E. D. A. (1986). Pesquisa em educação: abordagens qualitativas. São Paulo: Editora Pedagógica e Universitária.

Marcílio, M. L. (1998). História social da criança abandonada. São Paulo: Hucitec.

Passetti, E. (1992). O menor no Brasil republicano. In M. Del Priore (Org.), História da criança no Brasil. São Paulo: Contexto.

Rizzini, I. (1995). Crianças e menores: do pátrio poder ao pátrio dever: um histórico da legislação para a infância no Brasil (1830 - 1990). In F. Pilotti \& I. Rizzini (Org.), A arte de governar crianças: a história das políticas sociais, da legislação e da assistência à infância no Brasil. Rio de Janeiro: Instituto Interamericano del Nino.

Silva, R. Pobreza eexclusão social no Brasil: 300 anos de políticas públicas para a criança brasileira. Santa Catarina: Unicef, 1998. Recuperado abril 30, 2008, disponível em <http:// www.facom.ufba.br/pretextos/silva1.html>.

Volpi, M. (Org.) (1999). O adolescente e o ato infracional (3a ed.). São Paulo: Cortez.

Volpi, M. (2001) Sem liberdade, sem direitos: a privação da liberdade na percepção do adolescente. São Paulo: Cortez.

Recebido em: 30/4/2010

Versão final reapresentada em: 25/10/2010

Aprovado em: 16/12/2010 